\title{
Effect of Subzero Treatment on the Microstructure and Mechanical Properties of Austempered Ductile Cast Iron
}

\author{
Chang-Yong Kang ${ }^{1}$, Kwang-Hee Lee ${ }^{1}$, Hae Ryong Jung ${ }^{2}$, \\ Gwang-Ho Kim ${ }^{3}$, Byoung-Suhk Kim ${ }^{3}$ and Ick-Soo Kim ${ }^{3, *}$ \\ ${ }^{1}$ Division of Advanced Materials Engineering, Pukyong National University, Busan, 608-739, Korea \\ ${ }^{2}$ Department of Automobile Engineering, Dongmyong University, Busan, 608-711, Korea \\ ${ }^{3}$ Department of Functional Machinery and Mechanics, Shinshu University, Ueda 386-8567, Japan
}

\begin{abstract}
We have investigated the effects of subzero treatment on microstructures and mechanical properties of austempered ductile cast irons. The retained austenite microstructure was transformed to martensite microstructure by subzero treatment and strain. The ratio of the transformation to martensite increased with decreasing the subzero treatment temperature. By decreasing the subzero treatment temperature and increasing the strain, the retained austenite of the specimens with more $\mathrm{Cu}$ contents was transformed more to martensite. While the values of strength and hardness increased by decreasing the subzero treatment temperature, the values of elongation and impact decreased. Moreover, the strength and hardness of the specimens with more $\mathrm{Cu}$ contents increases, whereas the values of elongation and impact decreased. As a result, it was found that an addition of $\mathrm{Cu}$ in subzero treatment of the specimens had a little effect on the strength and hardness, but had a significant effect on the impact values. [doi:10.2320/matertrans.MRA2008440]
\end{abstract}

(Received December 2, 2008; Accepted June 11, 2009; Published July 29, 2009)

Keywords: austempered ductile cast iron, subzero treatment, retained austenite, martensite, austempering treatment

\section{Introduction}

Austempered ductile cast irons prepared by austempering treatment of ductile cast irons retain a relatively significant amount of the austenite microstructures, except for the bainite microstructure. Because the mechanical properties essentially depend on both bainite and retained austenite microstructures, austempered ductile cast irons have very high strength and excellent toughness. Therefore, they have been used as a substitute for forgings. In addition, austempered ductile cast irons allow easy preparation of complicated machine parts, thus extensively used for many structural applications in the automotive, defense, earthmoving machinery, railroad, and similar industries. ${ }^{1,2)}$

The mechanical property of austempered ductile cast irons depends on the bainite microstructure formed by austempering treatment, but also drastically on the volume fraction and stability of retained austenite microstructure in austempered ductile cast irons, ${ }^{10}$ ) which is due to a transformation of retained austenite to martensite microstructures via a plastic working, such as rolling, forging etc., indicating a deformation induced by plastic flow, or a subzero treatment that permits the austenite-to-martensite transformation by lowering the temperature below Ms point, which is the temperature transforming the retained austenite into martensite microstructure. ${ }^{2-9)}$ Therefore, the qualitative and quantitative studies on the volume fraction and stability of retained austenite microstructure in austempered ductile cast irons should be further carried out. In this work, in order to clarify such issues, the ductile cast irons with different $\mathrm{Cu}$ contents were used as specimens. Copper is an austenite stabilizing element. In the austempering process, copper can restrain the forming of carbide. It is therefore believed that the volume fraction of retained austenite increases by increasing $\mathrm{Cu}$

*Corresponding author, E-mail: kim@shinshu-u.ac.jp contents, and then results in an increased ratio of transformation into martensite via a subzero treatment. ${ }^{11,12}$ ) We explored quantitative analysis of the microstructures as well as the mechanical properties of austempered and subzero-treated ductile cast irons.

\section{Experimental Methods}

\subsection{Materials and thermal treatment}

Each specimen used in this study was dissolved in a cupola, and cast in the form of a Y-block (KSD4302A) to yield an ingot, which was then subjected to testing. The specimens were sphere-shaped $(>93 \%)$. Table 1 and 2 illustrate the chemical composition and microstructural data of the specimen, respectively. The thermal treatment of specimen was carried out as follows. The specimen was austenitized in a salt bath at $880^{\circ} \mathrm{C}$ for $1 \mathrm{~h}$, and then immediately added to a salt bath that was set to the austempering temperature of $350^{\circ} \mathrm{C}, 400^{\circ} \mathrm{C}$, and $450^{\circ} \mathrm{C}$, respectively. Afterwards, the specimen was maintained at this austempering temperature for an austempering time ranging from 30 to $10,030 \mathrm{~s}$ and then water-cooled. The

Table 1 Chemical composition of specimens (mass\%).

\begin{tabular}{ccccccccc}
\hline Spec. & Fe & $\mathrm{C}$ & $\mathrm{Si}$ & $\mathrm{Mn}$ & $\mathrm{P}$ & $\mathrm{S}$ & $\mathrm{Mg}$ & $\mathrm{Cu}$ \\
\hline $\mathrm{A}$ & Bal & 3.40 & 2.50 & 0.21 & 0.01 & 0.01 & 0.05 & 0.15 \\
B & Bal & 3.60 & 2.60 & 0.23 & 0.02 & 0.01 & 0.04 & 0.56 \\
\hline
\end{tabular}

Table 2 Microstructural analysis of ductile cast iron for as cast.

\begin{tabular}{ccccc}
\hline $\begin{array}{c}\text { Struc. } \\
\text { Spec. }\end{array}$ & Ferrite (\%) & Perlite $(\%)$ & Graphite $(\%)$ & $\begin{array}{c}\text { Mean diameter of } \\
\text { graphite module }(\mu \mathrm{m})\end{array}$ \\
\hline A & 67.9 & 22.2 & 9.8 & 17.8 \\
B & 44.2 & 44.3 & 11.5 & 21.5 \\
\hline
\end{tabular}


subzero treatment of austempered ductile cast irons was carried out by quenching the specimens to $-40^{\circ} \mathrm{C},-70^{\circ} \mathrm{C}$, and $-196^{\circ} \mathrm{C}$, respectively, and followed by maintaining for $30 \mathrm{~min}$. Each lower temperature was achieved by pure or mixture of methanol, dry ices, and liquid nitrogen. The carbon contents in the retained austenite phase were measured by energy dispersive x-ray spectroscopy (JEOL, JSM-6300) and auger electron spectroscopy (VG Scientific, MICROLAB 350). Auger analysis was carried out with a primary electron beam of $10 \mathrm{keV}$, with a detection area of $100 \mu \mathrm{m} \times 100 \mu \mathrm{m}$. The degree of carbon contents was given by the ratio of the Auger peak height of carbon $(272 \mathrm{eV})$ to that of iron at $703 \mathrm{eV}$ (i.e. Auger peak height ratio, PHR).

\subsection{Qualitative and quantitative analysis of microstruc- tures}

The microstructures of as-cast ductile cast iron and austempering and subzero-treated ductile cast iron were studied using optical microscopy (OM). The volume fraction of graphite was obtained by using image analyzer. X-ray diffraction (XRD) analysis was performed to estimate both the volume fraction of retained austenite in austempered ductile cast irons and the volume fraction of martensite when austempered ductile cast iron was subjected to subzero treatment. XRD was conducted using monochromatic Mo$\mathrm{K} \alpha$ radiation along with an angular range of $10^{\circ}<2 \theta<40^{\circ}$ at a scanning rate of $2 \theta=1.0^{\circ} / \mathrm{min}$. The volume fraction of the crystalline peaks corresponding to each phase was determined by Miller method ${ }^{13)}$ using the integrated intensities of martensite and austenite.

\subsection{Mechanical properties}

The tensile tests of as-cast ductile iron and austempering and subzero-treated ductile cast iron were carried out by using an Instron machine type (Model EZ-S500, Japan) at cross head speed of $1.0 \mathrm{~mm} / \mathrm{min}$ at room temperature. The hardness test was performed by using a micro-Vicker's hardness tester with a load of $1.0 \mathrm{~kg}$, and the average values from at least 5 test samples were reported in this paper. The impact measurements were taken with a Charpy impact tester. The specimens with a V-shaped notch of $2 \mathrm{~mm} \times$ $2 \mathrm{~mm}$ (JIS-2) were austempering and subzero-treated, and then used for a Charpy impact test.

\section{Results and Discussion}

\subsection{Microstructural analysis}

Figure 1 shows the optical micrographs of as-cast ductile cast iron, (a) A specimen ( $\mathrm{Cu}$ contents $\sim 0.15 \%$ ) and (b) B specimen $(\mathrm{Cu}$ contents $\sim 0.56 \%)$, respectively. As seen in Fig. 1, spherical graphite was observed in both pearlite and ferrite microstructures. More than $93 \%$ of the observed graphite structures were sphere-shaped, and bull's eye microstructures characteristic of ductile cast iron were also observed. As seen in Table 2, the B specimen with higher $\mathrm{Cu}$ contents exhibited the more pearlite and less ferrite microstructures than A-specimen. Figure 2 shows the optical micrographs of the specimen with bull's eye microstructures, which is austenitized at $880^{\circ} \mathrm{C}$ for $1 \mathrm{~h}$ and then austempered in salt bath maintained at $400^{\circ} \mathrm{C}$ for $30 \mathrm{~min}$. Both specimens
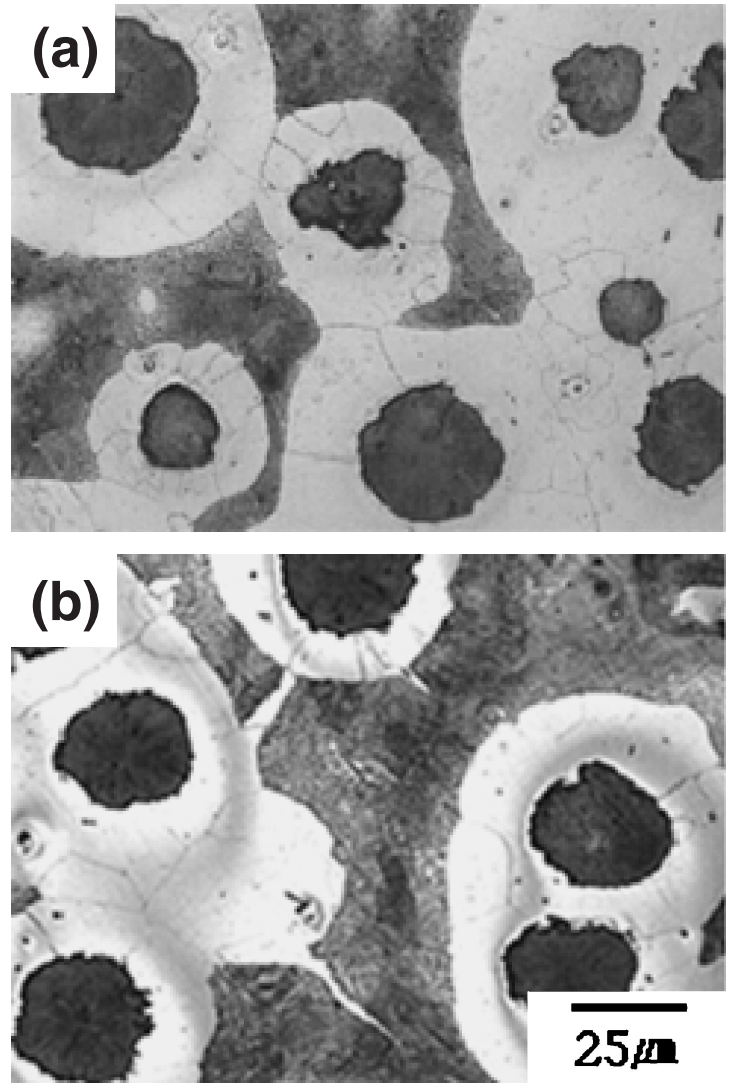

Fig. 1 Optical micrographs of as-cast ductile cast iron, (a) A specimen $(\mathrm{Cu}$ contents $\sim 0.15 \%$ ) and (b) B specimen (Cu contents $\sim 0.56 \%$ ).
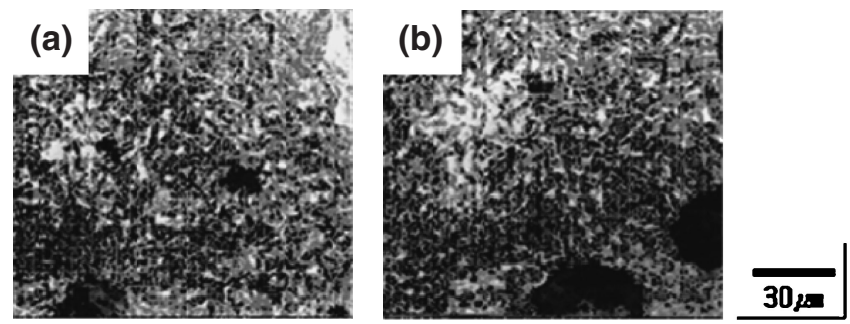

Fig. 2 Optical micrographs showing the effect of austempering at $400^{\circ} \mathrm{C}$ after austenitizing, (a) A specimen and (b) B specimen.

were transformed into a bainite microstructure by the austempering treatment. Figure 3 shows the optical micrographs of two specimens with different $\mathrm{Cu}$ contents. When the specimens were subjected to austempering process at $400^{\circ} \mathrm{C}$ for $30 \mathrm{~min}$, and followed by further subzero treatment at $-196^{\circ} \mathrm{C}$, the retained austenite will be transformed into martensite. ${ }^{6)}$ However, such transformation into martensite was not observed in the OM micrograph, suggesting that the microstructure obtained by subzero treatment of austempered ductile cast iron showed the similar bainite microstructure to that of austempered specimen.

\subsection{Effect of austempering treatment on microstructure}

Figure 4 shows the effects of the austempering temperature on the carbon contents in retained austenite and volume fraction of retained austenite in austempered ductile cast irons. Both carbon contents in retained austenite and volume 

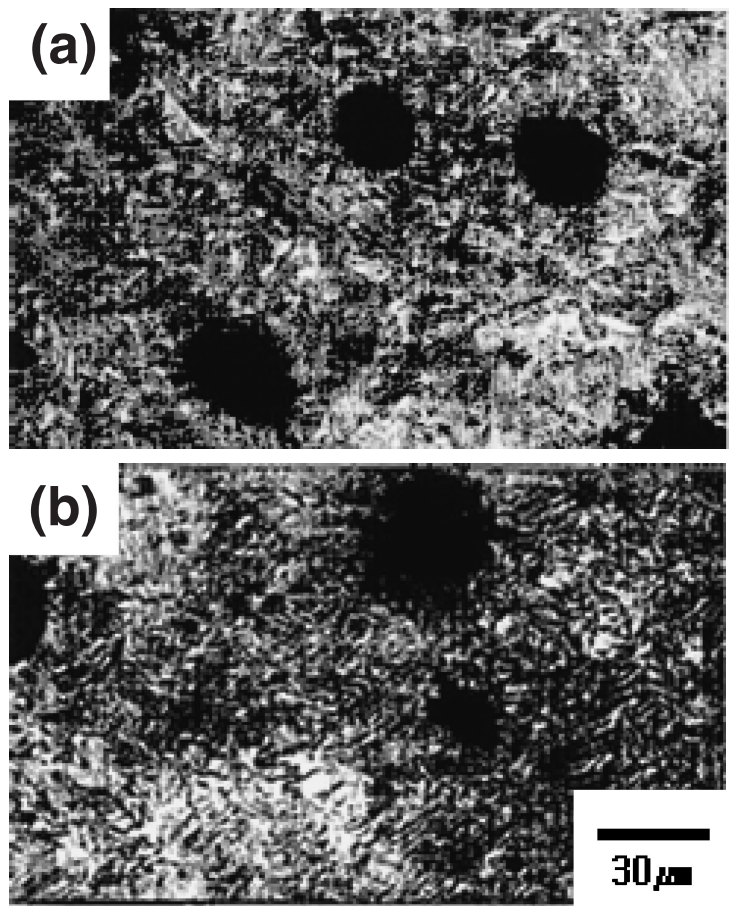

Fig. 3 Optical micrographs showing the effect of subzero treatment at $-196^{\circ} \mathrm{C}$, (a) A specimen and (b) B specimen.

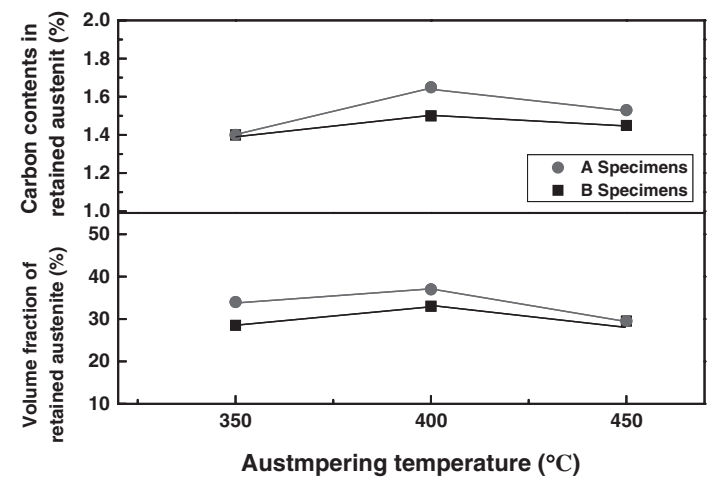

Fig. 4 Effect of austempering temperature on the carbon contents in retained austenite and volume fraction of retained austenite in austempered ductile cast iron.

fraction of retained austenite in austempered ductile cast irons increased a little (even smaller variation) when the specimen was subjected to austempering treatment at $400^{\circ} \mathrm{C}$. This is due to the higher carbon contents at the austempering temperature of $400^{\circ} \mathrm{C}$, and results in an enhanced stability of retained austenite microstructure and thereby transformation less into martensite. Figure 5 shows the effects of the austempering time on the carbon contents in retained austenite and volume fraction of retained austenite in austempered ductile cast irons. As the austempering time increased, the carbon contents sharply increased until the austempering time was $1000 \mathrm{~s}$, and then it leveled off (top, Fig. 5). The effect of the austempering time on the volume fraction of retained austenite also showed the similar behavior to those of carbon contents (bottom, Fig. 5). As a result, we found that the volume fraction of retained austenite in austempered ductile cast irons was affected by the carbon contents in retained austenite.

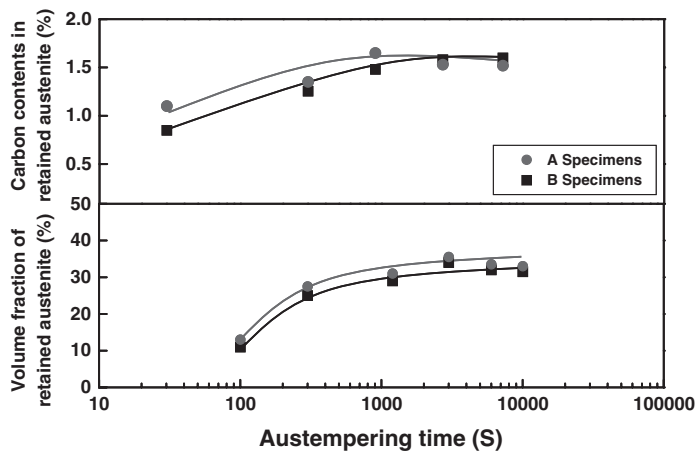

Fig. 5 Effect of austempering time on carbon contents in retained austenite and volume fraction of retained austenite in austempered ductile cast iron.

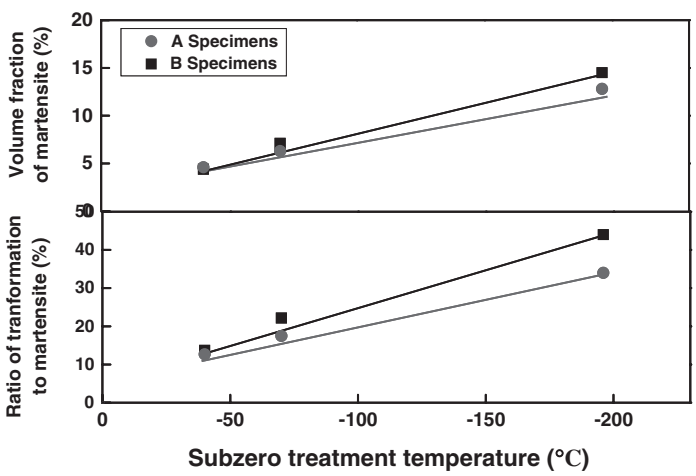

Fig. 6 Effect of subzero treatment temperature on the volume fraction of martensite and ratio of transformation to martensite in austempered ductile cast iron.

\subsection{Effect of subzero treatment and deformation on microstructure}

Figure 6 shows the effects of the subzero treatment temperature on the volume fraction of martensite and ratio of transformation of the retained austenite into martensite in austempered ductile cast iron. As seen in Fig. 6, when the specimen was subjected to subzero treatment temperature at $-40^{\circ} \mathrm{C}$ about $13 \%$ of the retained austenite in A specimen was transformed into martensite. On the other hand, by lowering the subzero treatment temperature to $-196^{\circ} \mathrm{C}$, about $33 \%$ of the retained austenite in A specimen was transformed into martensite (bottom, Fig. 6), indicating that the volume fraction of martensite increased with decreasing the subzero treatment temperature (top, Fig. 6). It was therefore concluded that the volume fraction of martensite and ratio of transformation to martensite increased linearly with decreasing the subzero treatment temperature. Moreover, at the same subzero treatment temperature $=-196^{\circ} \mathrm{C}$, $\mathrm{B}$ specimen with higher $\mathrm{Cu}$ contents exhibited the more transformation of the retained austenite (of about 44\%) into martensite, due to an increased volume fraction of retained austenite in the austempering process.

In addition, it is reported that the retained austenite in austempered ductile cast irons can be transformed to martensite not only by subzero treatment, but also by a plastic working, such as rolling, forging etc. giving rise to a deformation induced by plastic flow. ${ }^{14,15)}$ Such deformation to martensite may significantly affect the mechanical 


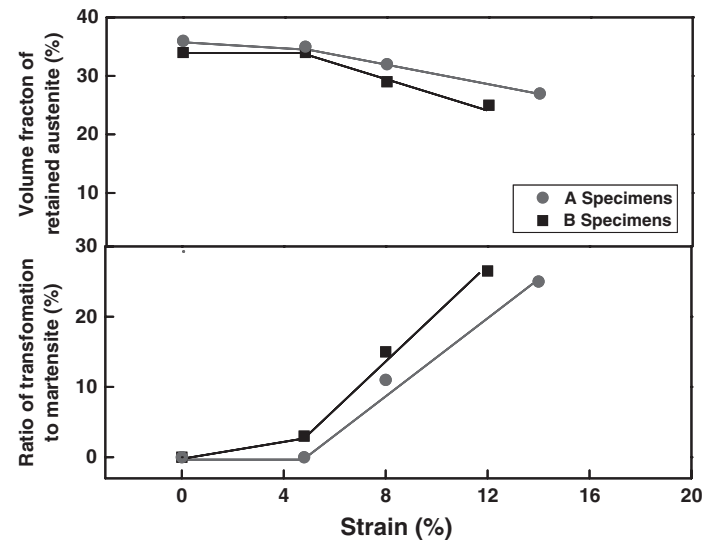

Fig. 7 Effect of strain on ratio of transformation into martensite and volume fraction of retained austenite in austempered ductile cast iron.

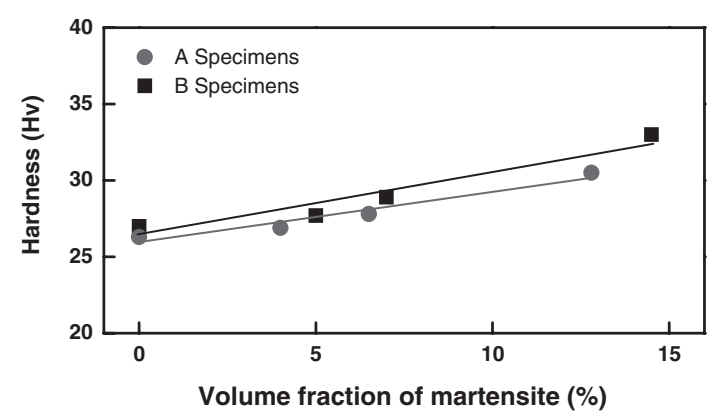

Fig. 8 Change in hardness on austempered ductile cast iron obtained by subzero treatment after austempering.

properties. Therefore, the effect of plastic working on the transformation behavior of the retained austenite into martensite microstructures was investigated, and the results were shown in Fig. 7. The volume fraction of the retained austenite in both specimens decreased with increasing the strain. On the other hand, the ratio of transformation of the retained austenite into martensite, which is induced by plastic flow, increased slowly at the initial strain below 5\%, and then increased rapidly at the strain above $5 \%$. Until the specimen was broken off, the retained austenite of about $25 \%$ in both specimens was transformed into martensite. It was found that the ratio of transformation into martensite in B-specimen with more $\mathrm{Cu}$ contents was higher than that of A-specimen.

\subsection{Effect of subzero treatment on mechanical property}

From the above results, it was concluded that the retained austenite in austempered ductile cast irons was transformed into martensite by subzero treatment. Furthermore, it can be considered that such transformation into martensite may affect the mechanical properties. We investigated the effect of the subzero treatment on mechanical properties. Figure 8 shows the change in hardness on the volume fraction of the martensite formed by subzero treatment. The hardness increased linearly with increasing the volume fraction of martensite. When both specimens were subjected to subzero treatment at $-196^{\circ} \mathrm{C}$, the hardness increased more than $18 \%$. Figure 9 shows the change in tensile strength on the volume fraction of the martensite formed by subzero treatment of the

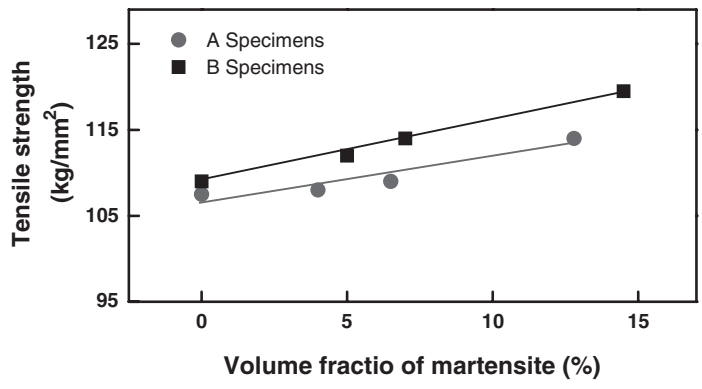

Fig. 9 Change in tensile strength on austempered ductile cast iron obtained by subzero treatment after austempering.

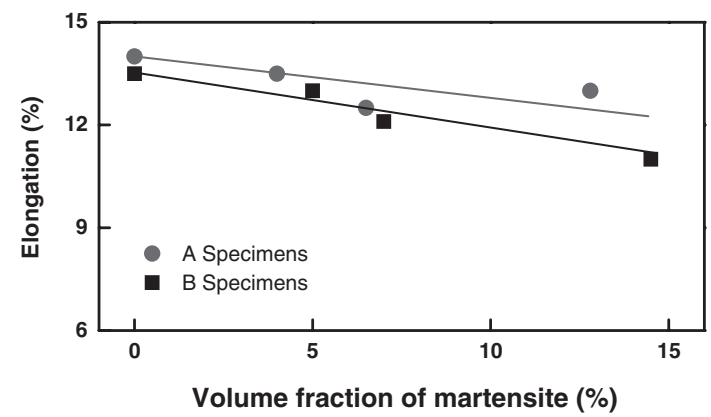

Fig. 10 Change in elongation on austempered ductile cast iron obtained by subzero treatment after austempering.

austempered ductile cast iron. The tensile strength in both specimens linearly increased with increasing the volume fraction of martensite. After subjecting the specimens to subzero treatment at $-196^{\circ} \mathrm{C}$, the tensile strength of $\mathrm{A}$ and $\mathrm{B}$ specimens increased $4 \%$ and $9 \%$, respectively. The tensile strength and hardness of $\mathrm{B}$ specimen with more $\mathrm{Cu}$ contents was a little higher than those of $\mathrm{A}$ specimen with less $\mathrm{Cu}$ contents, suggesting that an addition of $\mathrm{Cu}$ in subzero treatment of the specimens had a little effect on the tensile strength and hardness. As confirmed in Fig. 7, this result was due to the more transformation into martensite of B specimen with more $\mathrm{Cu}$ contents and an increased solid solution strengthened effect with increasing the $\mathrm{Cu}$ contents.

Figure 10 shows the change in elongation on the volume fraction of the martensite formed by subzero treatment of the austempered ductile cast iron. As seen in Fig. 10, the elongation in both specimens decreased linearly with increasing the volume fraction of martensite. This result was well coincide with the previous result that the martensite microstructure was formed by subzero treatment. Moreover, the elongation of $\mathrm{B}$ specimen with more $\mathrm{Cu}$ contents was lower that of A specimen with less $\mathrm{Cu}$ contents. Figure 11 shows the change in impact value on the volume fraction of the martensite formed by subzero treatment of the austempered ductile cast iron. The impact value in both specimens decreased sharply with increasing the volume fraction of martensite, and then slowly decreased when the volume fraction of martensite was above $5 \%$. As a result, it was found that the impact values of the specimens was significantly affected by subzero treatment. When the A and B specimens were subjected to subzero treatment at $-196^{\circ} \mathrm{C}$, the impact values were decreased to $20 \%$ and $40 \%$, respectively. 


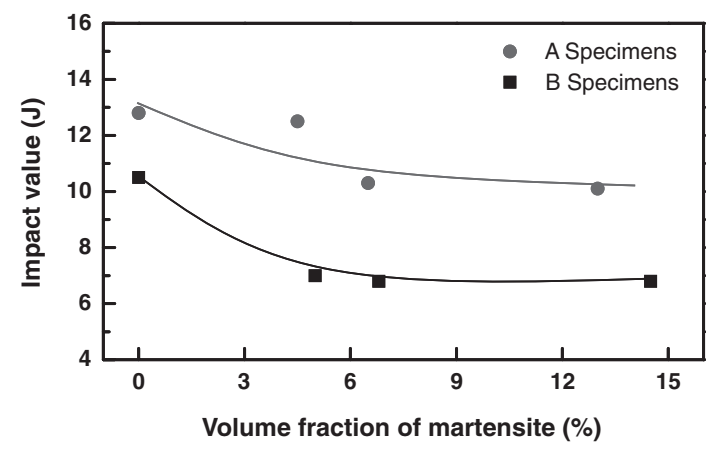

Fig. 11 Change in impact value on austempered ductile cast iron obtained by subzero treatment after austempering.

\section{Conclusions}

In this work, we have studied the effects of subzero treatment on microstructures and mechanical properties of austempered ductile cast irons.

The major conclusions are summarized below.

(1) Retained austenite microstructure was transformed into martensite microstructure by subzero treatment, and the ratio of the transformation into martensite increased with decreasing the subzero treatment temperature.

(2) The retained austenite microstructure of the specimen with more $\mathrm{Cu}$ contents was transformed more into martensite by subzero treatment.

(3) The ratio of transformation into martensite by deformation induced by a plastic flow increased slowly at the initial strain below 5\%, and then increased rapidly at the strain above $5 \%$. Until the specimen was broken off, about $25 \%$ of the retained austenite in both specimens was transformed into martensite.

(4) With decreasing the subzero treatment temperature, the values of hardness and tensile strength increased. The B specimen with more $\mathrm{Cu}$ contents showed higher values of hardness and tensile strength.

(5) With decreasing the subzero treatment temperature, the elongation and impact values decreased. The B specimen with more $\mathrm{Cu}$ contents showed lower elongation and impact value.

\section{REFERENCES}

1) J. F. Janowak and R. B. Gundlack: AFS Trans. 91 (1983) 377-388.

2) H. Mayer and B. Barbezat: Proc. 2nd International Conference on Austempered Ductile Iron, Ann Arbor, (University of Michigan, Ann Arbor, 1986) pp. 99-111.

3) Y. Ueda, M. Takita, H. Hiramitsu and T. Ando: J. J. F. S. 57 (1985) 728-732.

4) Y. Ueda, M. Takita and K. Shibayama: J. J. F. S. 60 (1988) 527-534.

5) T. Kobayashi, H. Yamamoto and Y. Tacabayashi: J. J. F. S. 59 (1987) $147-152$.

6) Y. Mizuno, Y. Hibino and H. Ishicawa: J. J. F. S. 62 (1990) 191-195.

7) Y. Ueda, M. Takita, H. Hiramitsu and T. Ando: J. J. F. S. 60 (1988) 186-190.

8) C. H. White and R. W. K. Honeycomb: JISI (1962) 457-466.

9) K. S. Raghavan, A. S. Sostic and M. J. Marinkowski: Trans. ASM 245 (1969) 1569-1578.

10) C. Y. Kang and J. H. Seong: J. Kor. Soc. Heat Treatment 4 (1991) 44-52.

11) Y. Mi: Scr. Metall. Mater. 32 (1995) 1313-1317.

12) W. Xu, M. Ferry and Y. Wang: Mater. Sci. Eng. A 390 (2005) 326333.

13) R. L. Miller: Trans. ASM 57 (1964) 191-199.

14) K. Hamaishi, H. Sueyoshi, J. Kiyofuji and Y. Nakamura: J. Japan Inst. Metals 59 (1995) 133-139.

15) Y. S. Jo and S. I. Kwun: J. Mater. Sci. 26 (1991) 4803-4807. 